\title{
Väkirehun koostumuksen ja elävän hiivan lisäyksen vaikutukset sonni- vasikoiden kasvuun ja rehun syöntiin
}

Arto Huuskonen ja Maiju Pesonen

Luonnonvarakeskus (Luke), Vihreä teknologia, Tutkimusasemantie 15, 92400 Ruukki, etunimi.sukunimi@luke.fi

\section{Tiivistelmä}

Tämän tutkimuksen ensimmäisenä tavoitteena oli verrata kotoista väkirehuseosta (ohra, rypsi, kivennäinen) ja teollista väkirehua vasikoiden alkukasvatuksessa. Toisena tavoitteena oli selvittää teolliseen väkirehuseokseen lisätyn elävän hiivan (Saccharomyces cerevisiae) mahdolliset vaikutukset. Kokeessa vertailtavat kolme väkirehuvaihtoehtoa olivat: 1) kotoinen viljapohjainen seos (litistetty ohra, rypsi, kivennäinen), 2) teollinen väkirehu, jossa ei käytetty elävää hiivaa ja 3) teollinen väkirehu, jossa oli lisättynä elävää hiivaa. Kokeessa oli koe-eläiminä maitorotuisia sonnivasikoita yhteensä 20 kappaletta kullakin koeruokinnalla. Kokeen alussa vasikat painoivat keskimäärin $56 \mathrm{~kg}$ ja olivat 21 päivän ikäisiä. Ternikasvatuskausi kesti kokeen alusta eläinten juotolta vieroitukseen noin 2,5 kuukauden ikään. Tämän jälkeinen teinikasvatuskausi kesti eläinten 6 kuukauden ikään saakka. Ternikaudella vasikat saivat 7 litraa juomarehua vuorokaudessa. Vasikat saivat koesuunnitelman mukaista väkirehua koko ruokintakokeen ajan. Ternikauden ajan väkirehun saanti oli vapaata. Teinikaudella väkirehun saanti rajoitettiin määrään $3 \mathrm{~kg} / \mathrm{pv} / \mathrm{eläin}$. Vasikat saivat vapaasti esikuivattua nurmisäilörehua ja vettä koko ruokintakokeen ajan.

Teollinen väkirehu paransi vasikoiden päiväkasvua ternikauden aikana kotoiseen väkirehuseokseen verrattuna (684 vs. $792 \mathrm{~g} / \mathrm{pv}$ ). Tämä johtui todennäköisesti ainakin osittain vasikoiden suuremmasta raakavalkuaisen saannista teollisella väkirehuruokinnalla (276 vs. $326 \mathrm{~g} / \mathrm{pv}$ ), koska kotoisen väkirehun raakavalkuaispitoisuus oli hieman teollista väkirehua matalammalla tasolla (167 vs. 198

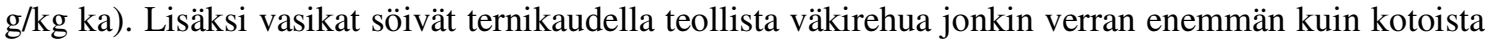
väkirehuseosta ( 0,52 vs. $0,68 \mathrm{~kg} \mathrm{ka} / \mathrm{pv})$, mikä ilmeisesti johtui teollisen väkirehun paremmasta maittavuudesta. Ternikaudella syntynyt ero päiväkasvuissa tasoittui teinikasvatuskaudella, eikä koko koeajalle lasketuissa kasvuissa tai elopainoissa kokeen lopussa ollut tilastollisesti merkitsevää eroa väkirehuruokintojen välillä. Numeerisesti kotoisella väkirehulla ruokitut vasikat olivat kokeen lopussa 10 kg kevyempiä kuin teollisella väkirehulla ruokitut vasikat (237 vs. $247 \mathrm{~kg}$ ). Väkirehuvaihtoehtojen valinnan järkevyyden ratkaisee viime kädessä taloudellinen kannattavuus. Tulos riippuu rehujen hinnasta ja vasikoiden hinnoittelusta. Raportointihetkellä voimassa olleen vasikkahinnaston mukaan kotoisella väkirehulla ruokitun vasikan myyntihinnaksi olisi muodostunut $655 €$ ja teollisella väkirehulla ruokitun vastaavasti $675 €$.

Elävän hiivan lisäyksellä teolliseen väkirehuseokseen ei tässä tutkimuksessa havaittu olevan mitään vaikutuksia vasikoiden tuotokseen tai terveyteen. Kirjallisuuden perusteella elävän hiivan tarjoamisesta voidaan saada hyötyä, jos tuotanto-olosuhteet ovat haasteelliset. On todennäköistä, että suomalaisissa tuotanto-olosuhteissa hiivalisäyksellä ei ole saavutettavissa kaikkia niitä hyötyjä, joita ulkomaisissa tutkimuksissa on raportoitu.

Asiasanat: vasikat, ruokinta, väkirehut, vilja, rypsi, elävä hiiva, kasvu, syönti 


\section{Johdanto}

Vasikoiden alkukasvatuskauden väkirehuruokinta voidaan toteuttaa viljalla, rypsitäydennyksellä sekä kivennäis- ja vitamiinilisäyksellä. Väkirehuruokintaan on myös tarjolla erilaisia teollisia väkirehuja, joiden etuina voidaan pitää viljaruokintaa parempaa maittavuutta ja rehun monipuolisempaa koostumusta. Viljaruokinnan etuna on puolestaan teollista väkirehua halvempi rehukustannus. Erilaisten bakteerivalmisteiden ja hiivojen käyttö kotieläinten ruokinnassa on lisääntynyt huomattavasti viimeisen 15 vuoden aikana. Näitä pidetään luonnollisempana ja parempana lisäaineena kuin useassa maassa vielä käytettyjä antibioottien kaltaisia lisäaineita. Saccharomyces cerevisiae on rehuteollisuudessa käytetyin hiivapreparaatti. Joidenkin tutkimusten perusteella Saccharomyces cerevisiae stimuloi pötsin mikrobeja muodostamaan tehokkaamman pötsimikrobiekosysteemin (Kumar ym. 1997, Enjalbert ym. 1999).

Kestävä Karjatalous (KESTO) -hankkeessa toteutetun tutkimuksen ensimmäisenä tavoitteena oli verrata kotoista väkirehuseosta (ohra, rypsi, kivennäinen) ja teollista väkirehua vasikoiden alkukasvatuksessa. Toisena tavoitteena oli selvittää teolliseen väkirehuseokseen lisätyn elävän hiivan (Saccharomyces cerevisiae) mahdolliset vaikutukset vasikoiden rehun syöntiin, kasvuun ja terveyteen.

\section{Aineisto ja menetelmät}

Ruokintakoe suoritettiin Luonnonvarakeskuksen (Luke) Siikajoen toimipisteessä. Koeasetelma toistettiin kahdessa osakokeessa, jotta saatiin mahdollisimman suuri havaintomäärä kullekin koeruokinnalle. Ensimmäinen osakoe alkoi huhtikuussa 2013 ja päättyi lokakuussa 2013. Toinen osakoe alkoi ensimmäisen jälkeen marraskuussa 2013 ja päättyi toukokuussa 2014. Molemmissa osakokeissa oli yhteensä $30 \mathrm{kpl}$ ayrshire-rotuisia sonnivasikoita. Kokeen alussa vasikat painoivat keskimäärin $56 \mathrm{~kg}$ ja olivat 21 päivän ikäisiä. Eläimet ryhmiteltiin molemmissa osakokeissa heti tulopäivänä satunnaisesti kuuteen viiden vasikan karsinaan kolmelle erilaiselle koeruokinnalle. Yhtä koeruokintaa kohti oli tällöin eläimiä yhteensä $20 \mathrm{kpl}$ (4 viiden eläimen karsinaa / ruokinta).

Tulosten laskennassa koe jaettiin ternikasvatuskauteen ja teinikasvatuskauteen. Ternikasvatuskausi kesti kokeen alusta eläinten juotolta vieroitukseen noin 2,5 kuukauden ikään. Tämän jälkeinen teinikasvatuskausi kesti eläinten 6 kuukauden ikään saakka. Vasikat kasvatettiin lämpimässä navetassa viiden vasikan ryhmäkarsinoissa, joiden koko oli 3,0 ×3,5 m. Tilaa yhtä vasikkaa kohti oli $2,1 \mathrm{~m}^{2}$.

Vasikat punnittiin kokeen alussa kahtena peräkkäisenä päivänä. Ternikaudella punnitus tapahtui tämän jälkeen kahden viikon välein ja teinikaudella neljän viikon välein. Ternikauden päättyessä sekä kokeen lopussa eläimet punnittiin kahtena peräkkäisenä päivänä, ja lopullisena tuloksena käytettiin kahden punnituksen keskiarvoa. Kaikki punnitukset tapahtuivat aamulla ennen ruokintaa.

Ternikaudella vasikat saivat päivässä 7 litraa juomarehua (Fokkamel Plus C, A-Rehu). Tarjotun juoman lämpötila oli $37^{\circ} \mathrm{C}$, ja juotto tapahtui juottoautomaatilla (Stand Alone 2 Plus, Förster, Engen, Germany; ohjelma: Kalbmanager 4.2). Juomarehua annosteltiin automaattiin 145 g / 1 litra vettä. Kahden ja puolen kuukauden iässä vasikat vieroitettiin juotolta. Vieroitus tapahtui asteittain vähentämällä juomarehun annosta noin puoli litraa päivässä kokeen seitsemänneltä viikolta alkaen, kunnes vasikat eivät enää saaneet juomarehua.

Kokeessa vertailtavat kolme väkirehuvaihtoehtoa olivat: 1) Kotoinen viljapohjainen seos (litistetty ohra, rypsi, kivennäinen), 2) Teollinen väkirehu, jossa ei käytetty elävää hiivaa ja 3) Teollinen väkirehu, jossa lisättynä elävää hiivaa.

Kotoisella väkirehulla ruokitut vasikat saivat väkirehuna litistetyn ohran, rypsin ja kivennäisen seosta. Väkirehuseos sisälsi litistettyä ohraa $75 \%$, rypsitiivistettä $20 \%$ sekä kivennäisseosta $5 \%$ tuorepainosta laskettuna. Ilman elävää hiivaa valmistettu teollinen väkirehu sisälsi ohraa (33,3\% tuorepainosta), rapsirouhetta $(17,4)$, vehnää $(8,0)$, ohrarehua $(7,2)$, melassileikettä $(7,0)$, soijarouhetta $(5,0)$, kauraa $(5,0)$, seosmelassia $(5,0)$, rypsipuristetta $(4,2)$, tiivistettyä tärkkelysrankkia $(4,0)$, ruokintakalkkia $(2,0)$, suojattua kasvirasvaa $(0,8)$ sekä kivennäisiä, vitamiineja ja aromiaineita $(1,1)$. Elävää hiivaa sisältänyt teollinen väkirehu oli edellä mainitun rehun kanssa identtinen lukuun ottamatta sitä, että se sisälsi elävää hiivaa (Saccharomyces cerevisiae Sc 47, 10 miljardia CFU/g hiivaa) 0,1 \% tuorepainosta, ja rehussa käytetyn ohran määrä oli vastaavasti matalampi.

Vasikat saivat samaa väkirehua koko ruokintakokeen ajan. Ternikauden ajan väkirehun saanti oli vapaata. Teinikaudella väkirehun saanti rajoitettiin maksimissaan määrään $3 \mathrm{~kg} / \mathrm{pv} / \mathrm{eläin.} \mathrm{Lisäksi}$ vasikat saivat vapaasti esikuivattua nurmisäilörehua ja vettä koko ruokintakokeen ajan. Päivittäinen rehunkulutus määritettiin punnitsemalla kuhunkin karsinaan menevän rehun määrä ennen rehunjakoa. 
Syömättä jäänyt rehu kerättiin päivittäin kaukaloista, punnittiin ja vähennettiin annetun rehun määrästä. Näin saatiin selville karsinakohtainen todellinen syönti.

Kokeessa käytetyistä rehuista kerättiin osanäytteitä, jotka yhdistettiin jokaisen neljän viikon ruokintajakson analyysinäytteeksi. Rehujen kemiallinen koostumus määritettiin Huuskosen (2013) kuvailemalla tavalla. Säilörehusta määritettiin lisäksi käymislaatu (pH, kokonaistyppi, liukoinen typpi, ammoniumtyppi, haihtuvat rasvahapot ja maito- sekä muurahaishappo) puristenestetitraukseen pohjautuvalla laatumäärityksellä (Moisio \& Heikonen 1989). Rehujen energia- ja valkuaisarvot laskettiin Luken (2015) kuvaamalla tavalla.

Tuloksia laskettaessa kahden osakokeen tulokset yhdistettiin. Kaikilla koekäsittelyillä oli 4 toistoa, jotka muodostuivat viiden vasikan ryhmistä. Koetulosten tilastollinen käsittely tehtiin SASohjelmiston MIXED-proseduurilla varianssianalyysillä. Testauksen koemallina oli täysin satunnaistettu koe. Koemalli oli $y_{\mathrm{jkl}}=\mu+\alpha_{\mathrm{j}}+\beta_{\mathrm{k}}+(\alpha \times \beta)_{\mathrm{jk}}+\mathrm{e}_{\mathrm{jkl}}$, missä $\mu$ on yleiskeskiarvo, $\alpha_{\mathrm{i}}$ on väkirehuruokinnan kiinteä vaikutus $(j=1,2,3), \beta_{\mathrm{k}}$ on osakokeen satunnaisvaikutus $(\mathrm{k}=1,2)$ ja $\mathrm{e}_{\mathrm{ij}}$ on virhetermi. Koekäsittelyjen väliset tilastolliset erot testattiin kahdella ortogonaalisella kontrastilla: 1) kotoinen viljapohjainen seos vs. teolliset täysrehut ja 2) elävää hiivaa sisältävä teollinen täysrehu vs. hiivaton teollinen täysrehu.

\section{Tulokset ja tulosten tarkastelu \\ Koerehut}

Kokeessa käytettyjen rehujen kemialliset koostumukset ja rehuarvot on esitetty taulukossa 1 . Kokeessa käytetty nurmisäilörehu oli kohtuullisen hyvin sulavaa (D-arvo $665 \mathrm{~g} / \mathrm{kg} \mathrm{ka}$ ) ja sisälsi raakavalkuaista $138 \mathrm{~g} / \mathrm{kg}$ ka. Säilörehu oli rajoitetusti käynyttä ja säilönnälliseltä laadultaan hyvää (Taulukko 1). Teolliset väkirehut sisälsivät kotoista väkirehuseosta enemmän raakavalkuaista, rasvaa ja kuitua. Kotoinen väkirehuseos sisälsi puolestaan enemmän tärkkelystä sekä hieman enemmän muuntokelpoista energiaa ja vähemmän raakavalkuaista kuin teolliset väkirehut.

Taulukko 1. Kokeessa käytettyjen rehujen kemiallinen koostumus ja rehuarvot.

\begin{tabular}{lccccc} 
& Säilörehu & Juomarehu & $\begin{array}{c}\text { Kotoinen } \\
\text { väkirehu }\end{array}$ & $\begin{array}{c}\text { Teollinen } \\
\text { väkirehu, } \\
\text { ei hiivaa }\end{array}$ & $\begin{array}{c}\text { Teollinen } \\
\text { väkirehu, } \\
\text { elävä hiiva }\end{array}$ \\
\hline Kuiva-aine (ka), g/kg & 287 & 943 & 885 & 856 & 865 \\
Orgaaninen aine, g/kg ka & 932 & 910 & 965 & 920 & 922 \\
Raakavalkuainen, g/kg ka & 138 & 216 & 167 & 203 & 193 \\
Neutraalidetergenttikuitu, g/kg ka & 589 & 2 & 216 & 221 & 260 \\
Raakarasva, g/kg ka & 39 & 114 & 22 & 38 & 40 \\
Tärkkelys, g/kg ka & 5 & 100 & 445 & 313 & 295 \\
Muuntokelpoinen energia, MJ/kg ka & 10,6 & & 12,7 & 12,4 & 12,4 \\
OIV, g/kg ka & 79 & & 104 & 116 & 116 \\
PVT, g/kg ka & 19 & & 14 & 36 & 36 \\
D-arvo, g/kg ka & 665 & & & & \\
Säilörehun syönti-indeksi & 104 & & & & \\
Säilörehun ME-indeksi & 101 & & & & \\
Säilörehun säilönnällinen laatu & & & & & \\
pH & 3,96 & 11 & & & \\
Haihtuvat rasvahapot, g/kg ka & 41 & & & & \\
Maito- ja muurahaishappo, g/kg ka & 56 & & & & \\
Sokeri, g/kg ka & & & & & \\
Kokonaistypestä, g/kg & 39 & & & & \\
$\quad$ Ammoniumtyppi & & & & & \\
Liukoinen typpi & 423 & & & & \\
\hline
\end{tabular}

\section{Rehujen syönti ja ravintoaineiden saanti}

Ternikauden aikana vasikat söivät juomarehun kuiva-ainetta keskimäärin $0,72 \mathrm{~kg} / \mathrm{pv}$, eikä juomarehun saannissa ollut eroa koeryhmien välillä (Taulukko 2). Juomarehun kulutus vastasi kaikilla koeruokinnoilla lähes sen suurinta suunniteltua käyttömäärää. Väkirehujen keskimääräinen syönti oli ternikaudella 0,63, teinikaudella 2,47 ja kokeen aikana keskimäärin $1,86 \mathrm{~kg} \mathrm{ka} / \mathrm{pv}$. Kotoista väkirehuseosta saaneiden vasikoiden väkirehun syönti oli ternikaudella hieman vähäisempää kuin teollisia väkire- 
huseoksia saaneiden vasikoiden väkirehun syönti ( 0,52 vs. $0,68 \mathrm{~kg} \mathrm{ka} / \mathrm{pv}, \mathrm{P}=0,14)$. Sen sijaan teinikaudella ja keskimäärin koko kokeen aikana ei vastaavaa eroa havaittu. Verrattaessa teollisia väkirehuja keskenään elävän hiivan lisäyksellä ei ollut vaikutusta väkirehun syöntiin millään koejaksolla (Taulukko 2). Väkirehun syönti lisääntyi kaikilla koeryhmillä tasaisesti siihen saakka, kunnes saanti rajoitettiin määrään $3 \mathrm{~kg} / \mathrm{pv} /$ eläin $(\sim 2,6 \mathrm{~kg} \mathrm{ka})$. Säilörehun syöntimäärissä ei havaittu eroja ruokintaryhmien välillä (Taulukko 2).

Vasikoiden kuiva-aineen syönti oli ternikaudella 1,62, teinikaudella 5,22 ja kokeen aikana keskimäärin 4,03 kg ka/pv. Syöntimäärissä ei havaittu tilastollisesti merkitseviä eroja ruokintaryhmien välillä (Taulukko 2). Ternikaudella vasikoiden päivittäisestä kuiva-aineen kulutuksesta keskimäärin 44 $\%$ muodostui juomarehusta, $17 \%$ säilörehusta ja $39 \%$ väkirehusta. Teinikaudella vasikoiden kuivaaineen saannista keskimäärin 47 \% tuli väkirehusta ja $53 \%$ säilörehusta. Vasikoiden energian saannissa ei havaittu tilastollisesti merkitseviä eroja ruokintaryhmien välillä millään koejaksolla.

Teollisten väkirehujen välisessä vertailussa ei havaittu minkäänlaisia eroja vasikoiden ravintoaineiden saannissa (Taulukko 2). Sen sijaan kotoisen väkirehuseoksen ja teollisten väkirehujen välille muodostui eroja, jotka näkyivät ennen kaikkea raakavalkuaisen, rasvan ja tärkkelyksen saanneissa. Nämä erot luonnollisesti heijastelivat eroja väkirehujen kemiallisessa koostumuksessa. Teollisella väkirehulla ruokitut vasikat saivat ternikauden aikana $18 \%$ enemmän raakavalkuaista $(\mathrm{P}=0,08)$ ja 13 $\%$ enemmän rasvaa $(\mathrm{P}=0,07)$ kuin kotoisella väkirehulla ruokitut vasikat (Taulukko 2$)$. Vastaavasti teinikauden aikana teollisella väkirehulla ruokitut vasikat saivat $13 \%$ enemmän raakavalkuaista $(\mathrm{P}<0,05)$ ja $25 \%$ enemmän rasvaa $(\mathrm{P}<0,05)$ mutta $30 \%$ vähemmän tärkkelystä $(\mathrm{P}<0,05)$ kuin kotoisella väkirehulla ruokitut vasikat.

Taulukko 2. Vasikoiden rehun syönti ja ravintoaineiden saanti ruokintakokeen aikana.

\begin{tabular}{|c|c|c|c|c|c|c|}
\hline & $\begin{array}{l}\text { Kotoinen } \\
\text { väkirehu }\end{array}$ & $\begin{array}{l}\text { Teollinen } \\
\text { väkirehu, } \\
\text { ei hiivaa }\end{array}$ & $\begin{array}{l}\text { Teollinen } \\
\text { väkirehu, } \\
\text { elävä hiiva }\end{array}$ & $\mathrm{SEM}^{1}$ & $\mathrm{C}^{2}$ & $\mathrm{C} 2^{3}$ \\
\hline \multicolumn{7}{|l|}{ Ternikausi (ikä 0,5 - 2,5 kk) } \\
\hline juomarehu, kg ka/pv & 0,72 & 0,71 & 0,72 & 0,010 & 0,65 & 0,47 \\
\hline väkirehu, kg ka/pv & 0,52 & 0,69 & 0,67 & 0,075 & 0,14 & 0,73 \\
\hline säilörehu, kg ka/pv & 0,28 & 0,30 & 0,25 & 0,073 & 0,90 & 0,18 \\
\hline kokonaissyönti, kg ka/pv & 1,52 & 1,70 & 1,64 & 0,068 & 0,22 & 0,59 \\
\hline energian saanti, MJ ME/pv & 22,4 & 24,1 & 23,5 & 0,86 & 0,32 & 0,66 \\
\hline raakavalkuainen, g/pv & 276 & 334 & 318 & 12,5 & 0,08 & 0,45 \\
\hline rasva, $\mathrm{g} / \mathrm{pv}$ & 107 & 121 & 120 & 3,2 & 0,07 & 0,98 \\
\hline tärkkelys, g/pv & 332 & 308 & 284 & 23,3 & 0,30 & 0,52 \\
\hline $\mathrm{NDF}, \mathrm{g} / \mathrm{pv}$ & 292 & 350 & 346 & 28,9 & 0,17 & 0,89 \\
\hline \multicolumn{7}{|l|}{ Teinikausi (ikä 2,5 - 6 kk) } \\
\hline väkirehu, $\mathrm{kg} \mathrm{ka/pv}$ & 2,48 & 2,48 & 2,46 & 0,031 & 0,84 & 0,74 \\
\hline säilörehu, kg ka/pv & 2,72 & 2,80 & 2,73 & 0,007 & 0,74 & 0,66 \\
\hline kokonaissyönti, kg ka/pv & 5,20 & 5,27 & 5,19 & 0,239 & 0,84 & 0,67 \\
\hline energian saanti, MJ ME/pv & 61,5 & 60,4 & 59,4 & 2,56 & 0,43 & 0,67 \\
\hline raakavalkuainen, g/pv & 768 & 890 & 852 & 50,0 & 0,04 & 0,27 \\
\hline rasva, $\mathrm{g} / \mathrm{pv}$ & 163 & 204 & 206 & 11,5 & 0,02 & 0,84 \\
\hline tärkkelys, g/pv & 1276 & 915 & 862 & 41,0 & 0,02 & 0,46 \\
\hline $\mathrm{NDF}, \mathrm{g} / \mathrm{pv}$ & 2111 & 2196 & 2247 & 120,9 & 0,30 & 0,64 \\
\hline \multicolumn{7}{|l|}{ Koko koeaika (ikä 0,5 - 6 kk) } \\
\hline juomarehu, $\mathrm{kg} \mathrm{ka} / \mathrm{pv}$ & 0,24 & 0,24 & 0,24 & 0,003 & 0,64 & 0,46 \\
\hline väkirehu, kg ka/pv & 1,83 & 1,88 & 1,86 & 0,037 & 0,42 & 0,73 \\
\hline säilörehu, kg ka/pv & 1,91 & 1,97 & 1,91 & 0,177 & 0,77 & 0,59 \\
\hline kokonaissyönti, kg ka/pv & 3,98 & 4,09 & 4,01 & 0,175 & 0,62 & 0,64 \\
\hline energian saanti, MJ ME/pv & 48,5 & 48,3 & 47,5 & 1,87 & 0,70 & 0,66 \\
\hline raakavalkuainen, $\mathrm{g} / \mathrm{pv}$ & 604 & 705 & 674 & 36,2 & 0,05 & 0.30 \\
\hline rasva, $\mathrm{g} / \mathrm{pv}$ & 144 & 177 & 178 & 8,6 & 0,02 & 0,87 \\
\hline tärkkelys, g/pv & 962 & 713 & 670 & 29,6 & 0,02 & 0,41 \\
\hline NDF, $g / p v$ & 1506 & 1583 & 1615 & 91,4 & 0,27 & 0,70 \\
\hline
\end{tabular}




\section{Kasvu ja rehun hyväksikäyttö}

Vasikat painoivat kokeen alussa keskimäärin $56 \mathrm{~kg}$. Juotolta vieroitettaessa eläinten paino oli keskimäärin $98 \mathrm{~kg}$ ja kokeen päättyessä $243 \mathrm{~kg}$ (Taulukko 3). Koeryhmien välillä ei ollut tilastollisesti merkitseviä eroja elopainoissa, vaikka kotoista väkirehuseosta saaneet vasikat olivatkin hieman muita ryhmiä kevyempiä sekä juotolta vieroitettaessa että kokeen päättyessä. Teollisten väkirehujen keskinäisessä vertailussa ei havaittu minkäänlaisia eroja vasikoiden elopainoissa, kasvuissa tai rehun hyväksikäytössä kummallakaan koejaksolla eikä keskimäärin kokeen aikana (Taulukko 3).

Vasikoiden päiväkasvu oli ternikaudella keskimäärin 756 g/pv, teinikaudella 1293 g/pv ja kokeen aikana keskimäärin $1114 \mathrm{~g} / \mathrm{pv}$. Teollista väkirehua saaneet vasikat kasvoivat ternikaudella keskimäärin $16 \%$ paremmin kuin kotoisella väkirehulla ruokitut vasikat $(\mathrm{P}=0,09)$. Teinikauden aikana vastaavaa kasvueroa ruokintaryhmien välillä ei havaittu. Koko kokeen ajalle laskettuna ero teollista ja kotoista väkirehua saaneiden vasikoiden päiväkasvussa oli vajaa $5 \%$ teollisen väkirehun hyväksi, mutta tämä ero ei muodostunut tilastollisesti merkitseväksi $(\mathrm{P}=0,41)$.

Ternikaudella havaittu teollista väkirehua saaneiden vasikoiden parempi päiväkasvutulos kotoiseen väkirehuseokseen verrattuna johtui todennäköisesti vasikoiden suuremmasta raakavalkuaisen saannista. Tämä oli puolestaan seurausta teollisen väkirehun korkeammasta raakavalkuaispitoisuudesta sekä hieman korkeammasta teollisen väkirehun syönnistä kotoiseen väkirehuseokseen verrattuna. Teollisen väkirehun hieman suurempi syöntimäärä oli mahdollisesti seurausta rehun sisältämästä melassista, jonka on todettu lisäävän väkirehun maittavuutta (mm. Spörndly \& Åsberg 2006).

Taulukko 3. Vasikoiden elopaino, kasvu ja rehun hyväksikäyttö ruokintakokeen aikana.

\begin{tabular}{|c|c|c|c|c|c|c|}
\hline & $\begin{array}{l}\text { Kotoinen } \\
\text { väkirehu }\end{array}$ & $\begin{array}{l}\text { Teollinen } \\
\text { väkirehu, } \\
\text { ei hiivaa }\end{array}$ & $\begin{array}{l}\text { Teollinen } \\
\text { väkirehu, } \\
\text { elävä hiiva }\end{array}$ & SEM $^{1}$ & $\mathrm{C}^{2}$ & $\mathrm{C} 2^{3}$ \\
\hline \multicolumn{7}{|l|}{ Elopaino, kg } \\
\hline alussa & 55 & 57 & 55 & 2,9 & 0,84 & 0,66 \\
\hline juotolta vieroitettaessa & 94 & 103 & 98 & 4,7 & 0,33 & 0,47 \\
\hline kokeen lopussa & 237 & 249 & 244 & 8,9 & 0,47 & 0,73 \\
\hline \multicolumn{7}{|l|}{ Päiväkasvu, g/pv } \\
\hline ternikausi & 684 & 824 & 760 & 40,8 & 0,09 & 0,38 \\
\hline teinikausi & 1276 & 1298 & 1304 & 48,0 & 0,71 & 0,94 \\
\hline keskimäärin kokeen aikana & 1079 & 1141 & 1123 & 41,5 & 0,41 & 0,79 \\
\hline \multicolumn{7}{|l|}{ Rehun hyväksikäyttö, kg ka / päiväkasvu-kg } \\
\hline ternikausi $(0,5-2,5 \mathrm{kk})$ & 2,38 & 2,17 & 2,21 & 0,097 & 0,24 & 0,80 \\
\hline teinikausi $(2,5-6 \mathrm{kk})$ & 4,17 & 4,08 & 4,02 & 0,208 & 0,53 & 0,79 \\
\hline keskimäärin kokeen aikana & 3,78 & 3,60 & 3,60 & 0,159 & 0,35 & 0,99 \\
\hline \multicolumn{7}{|l|}{ Energian hyväksikäyttö, MJ / päiväkasvu-kg } \\
\hline ternikausi $(0,5-2,5 \mathrm{kk})$ & 35,0 & 30,7 & 31,6 & 1,56 & 0,18 & 0,74 \\
\hline teinikausi $(2,5-6 \mathrm{kk})$ & 49,4 & 46,7 & 46,0 & 2,27 & 0,25 & 0,80 \\
\hline keskimäärin kokeen aikana & 46,2 & 42,6 & 42,6 & 1,74 & 0,19 & 0,98 \\
\hline
\end{tabular}

On mahdollista, että kasvuerot olisivat olleet pienemmät, jos kotoisen väkirehuseoksen ja teollisen väkirehun raakavalkuaispitoisuudet olisi päätetty koesuunnittelussa yhdenmukaistaa. Toisaalta aikaisemmassa teollista väkirehua ja kotoista väkirehuseosta vertailleessa tutkimuksessa (Huuskonen 2011) ei havaittu ruokintojen välisiä eroja sonni-vasikoiden päiväkasvuissa terni- eikä teinikaudella, vaikka tuossakin kokeessa kotoisen väkirehuseoksen (ohra, rypsi, kivennäinen) ja teollisen väkirehun välillä oli eroa raakavalkuaispitoisuuksissa teollisen väkirehun eduksi (169 vs. $185 \mathrm{~g} / \mathrm{kg}$ ka). Tästä huolimatta kotoista ja teollista väkirehua saaneiden vasikoiden päiväkasvuissa ei ollut merkitseviä eroja ternikauden (717 vs. $686 \mathrm{~g} / \mathrm{pv}$ ) tai teinikauden (1 355 vs. $1384 \mathrm{~g} / \mathrm{pv}$ ) aikana (Huuskonen 2011). Erot tässä raportoitavan ja Huuskosen (2011) raportoiman kokeen välillä saattavat johtua osaltaan eroista juomarehun käyttömäärissä. Huuskosen (2011) tutkimuksessa juomarehua annettiin juottokaudella 8,5 litraa eläintä kohti päivässä, mikä on 1,5 litraa tässä raportoitavaa koetta enemmän. Suurempi juottomäärä on todennäköisesti tasoittanut eroja väkirehuruokintojen välillä Huuskosen (2011) tutkimuksessa.

Tiedot rehun kuiva-aineen (kg ka/päiväkasvu-kg) ja energian (MJ/päiväkasvu-kg) hyväksikäytöstä kasvuun ternikaudella, teinikaudella ja keskimäärin kokeen aikana käyvät ilmi taulukosta 
Minkään mainitun muuttujan osalle ei syntynyt tilastollisesti merkitseviä eroja ruokintaryhmien välille kokeen aikana.

\section{Terveys}

Vasikoilla oli ripulia ternikauden aikana keskimäärin $3 \%$ koepäivistä. Koeryhmien välillä ei ollut eroja ripulien esiintymistiheydessä tai kestossa. Suurin osa ripulipäivistä ajoittui ensimmäisille koeviikoille, ja ensimmäiset ripulioireet olivat havaittavissa jo siinä vaiheessa, kun eläimiä alettiin siirtää koeruokinnoille. Siten koeruokinnat eivät olleet syynä ensimmäisten päivien ripulitapauksiin, vaan eläimet olivat saaneet tartunnan jo syntymätilallaan tai viimeistään eläinvälityksen yhteydessä. Kuljetuksen aiheuttama stressi sekä kasvatusolosuhteiden muutokset edistävät ripuleille altistumista ja tautien puhkeamista (Roth ym. 2009). On myös huomattava, että vaikka ensimmäisillä koejaksoilla esiintyi suhteellisen suuri määrä ripulipäiviä, niin koko kokeen keskiarvot ovat kaikilla ryhmillä tasolla, jollaisia vasikkakokeista on yleensä Suomessa raportoitu (mm. Saloniemi 2000, Huuskonen ym. 2005). Myöskään yskän tai puhaltumisten esiintymisessä ei ollut eroja koeryhmien välillä.

Elävällä hiivalla ei tässä kokeessa havaittu olevan mitään vaikutuksia vasikoiden tuotokseen tai terveyteen. Joissakin ulkomaisissa tutkimuksissa elävällä hiivalla on sen sijaan havaittu olevan positiivisia vaikutuksia. Esimerkiksi Lesmeister ym. (2004) osoittivat, että vasikoiden dieettiin lisätty elävä hiiva paransi rehuhyötysuhdetta, lisäsi päiväkasvua ja syöntiä. Aivan yhtä vakuuttavia tuloksia ei ole saatu nautojen loppukasvatuksen yhteydessä, sillä Mir \& Mir (1994) eivät saaneet elävän hiivan lisäyksellä eroja kontrollidieetteihin verrattuna. Tosin happaman pötsin esiintyvyys väheni kokeessa elävää hiivaa sisältävillä dieeteillä (Mir \& Mir 1994). Rehustuksessa annettu elävä hiiva on monissa tutkimuksissa lisännyt pötsin mikrobien määrää, mikrobipopulaation kasvua ja kuitua sulattavien mikrobien aktiivisuutta (Newbold ym. 1995, 1996, Mosoni ym. 2007). Lisäksi vasikoilla on ollut suuremmat kasvut, parantunut rehuhyötysuhde ja nopeutunut pötsin kehitys, kun vasikat ovat saaneet elävää hiivaa sisältäneitä dieettejä verrattuna dieetteihin, joissa ei ole ollut elävää hiivaa (Abu-Tarbousch ym. 1996, Galvao ym. 2005, Adams ym. 2008). Colen ym. (1992) tutkimuksessa hiivaa dieetissä saaneiden vasikoiden sairastavuus oli vähäisempää, lääkintäpäiviä oli vähemmän ja rehu-hyötysuhde oli parempi kuin vasikoilla, jotka eivät saaneet hiivaa dieetissä. Läpikäydyn kirjallisuuden perusteella elävän hiivan tarjoamisella voidaan saavuttaa hyötyjä erityisesti, jos tuotanto-olosuhteet ovat haasteelliset. Tämän vuoksi on todennäköistä, että suomalaisissa tuotanto-olosuhteissa ei ole saavutettavissa kaikkia niitä hyötyjä, joita ulkomaisissa tutkimuksissa on voitu osoittaa.

\section{Yhteenveto ja johtopäätökset}

Teollinen väkirehu paransi vasikoiden päiväkasvua ternikauden aikana kotoiseen väkirehuseokseen verrattuna. Tämä johtui todennäköisesti ainakin osittain vasikoiden suuremmasta raakavalkuaisen saannista teollisella väkirehuruokinnalla, koska kotoisen väkirehun raakavalkuaispitoisuus oli hieman teollista väkirehua matalammalla tasolla. Lisäksi vasikat söivät teollista väkirehua jonkin verran enemmän kuin kotoista väkirehuseosta, mikä ilmeisesti johtui teollisen väkirehun paremmasta maittavuudesta. Kokeessa käytetty suhteellisen matala juottomäärä (7 litraa/pv) todennäköisesti korosti väkirehuruokintojen välisiä eroja. Vastaavasti suurempi juottomäärä olisi saattanut tasoittaa eroja väkirehuruokintojen välillä. Ternikaudella syntynyt ero päiväkasvuissa tasoittui teinikasvatuskaudella eikä koko koeajalle lasketuissa kasvuissa eikä elopainoissa kokeen lopussa ollut tilastollisesti merkitsevää eroa väkirehuruokintojen välillä. Numeerisesti kotoisella väkirehulla ruokitut vasikat olivat kokeen lopussa noin $10 \mathrm{~kg}$ kevyempiä kuin teollisella väkirehulla ruokitut.

Väkirehuvaihtoehtojen valinnan järkevyyden ratkaisee viime kädessä taloudellinen kannattavuus. Suomessa suuri osa maitorotuisista sonneista kasvatetaan kolmivaihekasvatuksessa, jolloin eläimet ovat välikasvattamoissa 4-6 kuukauden ikään saakka, kunnes ne siirretään loppukasvattamoon. Jos loppukasvatus tapahtuu eri tilalla kuin välikasvatus, välitettävät eläimet hinnoitellaan painon mukaan. Tällöin välikasvattajan on mahdollista saada etua paremmin kasvaneista eläimistä. Tulos riippuu rehujen hinnasta ja vasikoiden hinnoitteluperusteista. Tämän tutkimuksen raportointihetkellä voimassa olleen A-Tuottajat Oy:n hinnaston mukaan kotoisella väkirehulla ruokitun vasikan hinnaksi olisi muodostunut $655 €$ ja teollisella väkirehulla ruokitun vasikan hinnaksi $675 €$. Hinta muodostuu perushinnasta, vasikan painon vaikutuksesta ja päiväkasvulisästä. Tässä tapauksessa vasikkakauden teollisesta väkirehusta kannattaisi maksaa vasikkaa kohti korkeintaan $20 €$ plus kotoisen väkire- 
huseoksen esikäsittelystä (mm. viljan litistys) aiheutuvan työkustannuksen verran enemmän kuin kotoisesta väkirehuseoksesta.

Elävän hiivan lisäyksellä teolliseen väkirehuseokseen ei havaittu tässä tutkimuksessa olevan mitään vaikutuksia vasikoiden tuotokseen tai terveyteen. Tulos poikkeaa useista ulkomaisista tutkimuksista, joissa elävän hiivan lisäyksellä on havaittu saavutettavan positiivisia vaikutuksia tuotokseen ja terveyteen. Kirjallisuuden perusteella elävän hiivan tarjoamisella on erityinen hyöty, jos tuotantoolosuhteet ovat haasteelliset. Tämän vuoksi on todennäköistä, että suomalaisissa tuotanto-olosuhteissa hiivalisäyksellä ei ole saavutettavissa kaikkia niitä hyötyjä, joita sen käytöstä on ulkomaisissa tutkimuksissa raportoitu.

\section{Kirjallisuus}

Abu-Tarboush, H.M., Al-Salady, M.Y. \& Keir El-Din, A.H. 1996. Evaluation of diet containing Lactobacilli on performance, fecal coliform, and Lactobacilli on young calves. Anim. Feed Sci. Tech. 57: 39-49.

Adams, M.C., Luo, J., Rayward, D., King, S., Gibson, R. \& Moghaddam, G.H. 2008. Selection of a novel direct-fed microbial to enhance weight gain in intensively reared calves. Anim. Feed Sci. Tech. 145: 41-52.

Cole, N.A., Purdy, C.W. \& Hutcheson, D.P. 1992. Influence of yeast culture on feeder calves and lambs. Journal of Animal Science 70: 1682-1690.

Enjalbert, F., Garrett, J.E., Moncoulon, R., Bayourthe, C. \& Chihoteau, P. 1999. Effects of yeast culture (Saccharomyces cerevisiae) on ruminal digestion in non-lactating dairy cows. Anim. Feed Sci. Tech. 76: 195206.

Galvao, K.N., Santos, J.E., Cosconi, A., Villasenor, M., Sischo, W.M. \& Berge, A.C. 2005. Effect of feeding live yeast products to calves with failure of passive transfer on performance and patterns of antibiotic resistance in fecal Escheria coli. Reprod. Nutr. Dev. 45: 427-440.

Huuskonen, A. 2011. Effects of barley grain compared to commercial concentrate or rapeseed meal supplementation on performance of growing dairy bulls offered grass silage-based diet. Agric. Food Sci. 20: 191-205.

Huuskonen, A. 2013. Performance of growing and finishing dairy bulls offered diets based on whole-crop barley silage with or without protein supplementation relative to a grass silage-based diet. Agric. Food Sci. 22: 424434.

Huuskonen, A., Khalili, H., Kiljala, J., Joki-Tokola, E. \& Nousiainen, J. 2005. Effects of vegetable fats versus lard in milk replacers on feed intake, digestibility, and growth in Finnish Ayrshire bull calves. J. Dairy Sci. 88: 3575-3581.

Kumar, U., Sareen, V.K. \& Singh, S. 1997. Effect of yeast culture supplement on ruminal microbial populations and metabolism in buffalo calves fed a high roughage diet. J. Sci. Food Agric. 73: 231-236. Lesmeister,

K.E. \& Heinrichs, A.J. 2004. Effects of corn processing on growth characteristics, rumen devel-opment, and rumen parameters in neonatal dairy calves. J. Dairy Sci. 87: 3439-3450.

Luke 2015. Rehutaulukot ja ruokintasuositukset. Luonnonvarakeskus. Saatavilla internetistä: www.luke.fi/rehutaulukot

Mir, Z. \& Mir, P.S. 1994. Effect of the addition of live yeast (Saccharomyces cerevisiae) on growth and carcass quality of steers fed high-forage or high-grain diets and on feed digestibility and in situ degradability. J. Anim. Sci. 72: 537-545.

Moisio, T. \& Heikonen, M. 1989. A titration method for silage assessment. Anim. Feed Sci. Tech. 22: 341-353. Mosoni, P., Chaucheyras-Durand, F., Béra-Maillet, C. \& Forano, E. 2007. Quantification by real-time PCR of cellulolytic bacteria in the rumen of sheep after supplementation of a forage diet with readily fermentable carbohydrates: effect of a yeast additive. J. Appl. Microbiol. 103: 2676-2685.

Newbold, C.J., Wallace, R.J., Chen, X.B. \& MacIntosh, F.M. 1995. Different strains of Saccharomyces cerevisiae differ in their effects on ruminal bacteria in vitro and in sheep. J. Anim. Sci. 73: 1811-1818.

Newbold, C.J., Wallace, R.J. \& MacIntosh, F.M. 1996. Mode of action of the yeast Saccharomyces cerevisiae as a feed additive for ruminants. Br. J. Nutr. 76: 249-261.

Roth, B.A., Keil, N.M., Gygax, L. \& Hillmann, E. 2009. Influence of weaning method on health status and rumen development in dairy calves. J. Dairy Sci. 92:645-656.

Saloniemi, H. 2000. Ryhmä- ja kylmäkasvatuksen vaikutukset vasikoiden rehujen syöntiin, käyttäytymiseen, kasvuun ja terveyteen. Teoksessa: Simonen, T. \& Saloniemi, H. (toim.) Kotieläinten tuotantoympäristötutkimus 1996-2000. Seminaariraportti 19.4.2000. s. 31-42.

Spörndly, E. \& Åsberg, T. 2006. Eating rate and preference of different concentrate components for cattle. J. Dairy Sci. 89: 2188-2199. 